\title{
INSTRUCTION DESIGN SYSTEM OF ALLAMA IQBAL OPEN UNIVERSITY: A VEHICLE FOR IMPROVEMENT OR MERE A SALOGON
}

\author{
Muhammad ASHFAQ \\ Education Department, \\ Khyber Pakhtunkhwa, \\ PAKISTAN \\ Dr. Muhammad Ajmal CHAUDRY \\ Allama Iqbal Open University, \\ Islamabad, PAKISTAN \\ Dr. Muhammad Javed IQBAL \\ Sarhad University, \\ Peshawar, PAKISTAN
}

\begin{abstract}
The main objective of this study was to ensure instructional quality, effectiveness, efficiency and enjoyment. Instructional design maximizes the value of the instructions for the learners. Instructional design include identifying instructional out-comes, developing instructional contents and established how instructional effectiveness will be evaluated. This study aimed to analyze the existing instructional design system of Allama Iqbal Open University, identify the possibilities of new innovations, to explore the gap between existing practices and opportunities of instructional design system and to suggest the strategies for improvement in instructional design system at Allama Iqbal Open University. The population of the study comprised 75 course writers, 25 course reviewers and 10 media producers at Allama Iqbal Open University. A sample of $100 \%$ was drawn. Questionnaires were used to collect the data. The results indicated that need assessment is conducted, courses are developed with standardized techniques, content are appropriate and placed in logical order. Creativity is maintained in course development process and courses are also provided on e-learning format. E-assessment techniques should be used and evaluation system is suitable to evaluate all components of the instructional design. Communication strategies should be up-dated and instructional design of Allama Iqbal Open University should be more innovative. Modern educational technology should be used and professional development opportunities are available for all stakeholders of the instructional design at Allama Iqbal Open University. The findings suggest that media laboratory may be established and to be launch innovative multimedia based education programs at Allama Iqbal Open University. Centre for Instructional Design may be developed for enhancement of delivery system. Creativity may be maintained in course production process and there is need to select appropriate media for transmission of courses. Instructional design of Allama Iqbal Open University may be modified to meet the future needs. E-learning and e-assessment techniques may be developed. Systematic and continuous research may be undertaken for future vision of the instructional design system by Allama Iqbal Open University.
\end{abstract}


Keywords: Distance education, instructional design, models, vehicle for improvement, innovations, instructional quality.

\section{INTRODUCTION}

Education is a basic need of any social, cultural and economic developmental plan. Education is a basic human right and nations plan their socio-economic development based upon welleducated masses. The fundamental purpose of education is to search the truth and develop the mental and physical qualities of man in such a manner that the probabilities of the humans may be comprehended Annick, and Brennen (2001). According to Edmonds (1994) that "the intrinsic human value of education is its ability to add meanings, values, knowledge, skills and competencies". This value contains information's, skills and experiences transmit through a mechanism. The instructional design is one and major amongst these mechanisms and components of education system. Instructional design describes the method concerned in systematic planning of instruction at the very basic stage Shambaugh (2006). It is the methodical growth of instructional stipulations by means of wisdom and instructional theory to make certain the eminence of training. Instructional design is an organized development of instructional strategies for using learning and instructional theories to insure the qualitative instruction. Parveen (2014) viewed that "instructional design is a comprehensive analysis of learning needs and objectives for the successful development of instructional system. Instructional design comprises upon the evolution of instructional activities and materials so also trial, test and evaluate the instructional and learner activities.

\section{APPROACHES OF INSTRUCTIONAL DESIGN}

Simonson, Smaldino, Albright, and Zvacek (2006) describe four approaches of instructional design as:

Linier- Designed Approach. This approach is based upon organization module which gives the liberty of transition to the learners, so they can go through from a series of tasks and readings in specific processions. Learning is organized in a sequence for obtaining educational objectives.

Branch-Designed Instruction. This branch gives more flexibility for accomplishing the tasks and readings. This draft is fundamentally linear regarding providing opportunities to learners for the further specific areas or to remove students' backwardness of instructions towards remedial areas.

Hyper Content Design. Topics of hyper content designs can be studied randomly and in a non-sequential way. They states additionally that students within their framework and had a control over the studied topics and they can do this without the direct control of instructor. This type of concepts comprises upon text and multimedia elements like audio, video, pictures and graphics.

Learner Directed Design. Learner directed design gives liberty to students for ascertaining navigation of courses completely. Learners formulate their own instructional schemes and even their instructional design as well. It is reckoned as constructivist design model which completely supports learner compulsive objectives. However, the author warns the learner that design needs a worthy talented and lots of talents for achieving success Simonson, Smaldino, Albright and Zvacek ( 2006). 


\section{INSTRUCTIONAL DESIGN MODELS}

The models of instructional design render the procedural framework for the system development of instruction. It comprises upon the components of instructional design process which included the determination of objectives and goals and the analysis of audience to be selected. It describes how the components of instructional strategies are incorporated to formulate a course of instruction Morphew (2000).

ADDIE Model. The model which perhaps used mostly for creating and delivery of the material of instruction is ADDIE Model. The stages of model are, to analyze learner characteristics, environment and the tasks which are to be learned. This model is helpful to design and develop the objectives of learning, select the instructional approach, to develop and create instructional or training materials, to implement, distribute and deliver the instructional materials and evaluation of achieved materials and the desired goals Morphew (2000). The steps of the models are planted by adopting generic approach system which itself bears a systematic nature. Formative evaluation is conducted for evaluating the value of all five steps separately and revisions is conducted wherever is needed for improvement. The outcome of the each step of this model is taken into consideration upon the subsequent phase. The rest of new models of instructional design are the variation of this model although their levels of complexity and specificity varied.

\section{Instructional Development Learning System (IDLS) Model}

IDLS model was primitively formulated and published by Peter in 1970 which comprises upon the components i. e. to design a task analysis, to develop criterion and performance measures, to develop interactive instructional materials and validation of the interactive instructional materials.

\section{Dick and Carey System Approach Model}

The Dick and Carey Systems Approach Model were primitively formulated by Walter Dick and Lou Carey and for the first time released for public in 1968 but later in 1978 it was published in the book of Walter Dick and Lou Carey entitled "The Systematic Design of Instruction". The most revision of model was done in 2005. They both made a significant contribution in the field of design by making a system view of championing being in opposition of viewing instruction system which is based on the concept of isolated parts which is focalizing on the interrelatedness of contents, context, instruction and learning. Dick, and Carey (1990) view that "it is one of the leading model of today which is based upon behavioral approach of instruction. The elements of this model are the learners, instructors, materials, delivery systems, instructional activities, learning performance and work altogether about students".

\section{Objectives Activities Resource (OAR) Model}

An instructional design model is designed for a specific context. It is used to deliver by a learning management system (LMS) courses of distance education at different levels of education. According to Smith and Ragan (1993) this model was designed to encounter four criterions:

- To maintain rigorous focus on the context of learning system.

- To create a simple graphical support and this alleviates communication among the originating stakeholders.

- To remain inclusive.

- To represent the clear order of operations in the developmental process of an online courses. 
Morrison, Ross and Kemp Model

A well organized design process proposed by Ross, Kemp and Morrison (2001) model which comprises upon nine reciprocally connected steps. These steps include, identify problems of instructional design, to specify relevant goals to examine the characteristics of learner, identify the contents of subject and to analyze task oriented elements which are relevant of instructional goals, describe instructional objectives for learners, to arrange the contents in sequence within each unit to maintain the logical learning, plan the delivery of instructions, develop instruments for evaluation and selection of supportive learning activities resources.

Smith and Ragan's Model

The model of Smith and Ragan (2004) is also comprised upon the systematic designing approach of instruction. It includes three stages which are: (a) analysis which is related with learners, learning context and tasks of learning. (b) strategy which includes organizational, management and delivery. (c) evaluation which covers formative evaluation, revisal and required alterations.

\section{INSTRUCTIONAL DESIGN SYSTEM OF OPEN UNIVERSITIES}

The distance universities of the world design and implement instructional design system, considering their demographic conditions and needs. The major universities are:

Instructional Design System at Open University of Sri-Linka

The Open University of Sri Lanka was established in 1980, as a first Open and Distance learning institute in Sri Lanka with an objective that the students may continue and pursue their studies through Open and Distance Learning (ODL) methods. Multimedia system is being used by the Open University of Sri Lanka for teaching and emphasis on the basic objective of the university. The students are assisted through various means that include printed texts, audios \& videos, day schooling, discussions, labs, tutor clinics, field works, study trips of industry and internet. Constant evaluation and final examinations are primary elements of the study system at Open University of Sri Lanka. Study package is primarily consisted of printed course material. The improvement and development of the reading skills in the students is also important, students are provided other helping material regarding a course that include practical and study guide, audio and video materials as the needs and requirements of the students.

\section{Instructional Design System at UK Open University}

United Kingdom is considered the hub of education and learning of all fields. Therefore, to meet the international standards the open university utilizes a range of means for distance learning that include printed material, disc-based software, DVDs, TV programs based on the courses and broadcasts by the BBC, other audio and video materials. In-house and external academic contributors prepare these materials and open university students also use thirdparty licensed materials. Tutors or Associate Lecturers assist the students in most modules, they give feedback on the students' work, and the students may meet them for the face-toface tutorials and may be contacted on telephone or through internet i.e. Skype, Email etc. Open university offers several short courses of ten credits having no assigned tutor however online conferencing service known as Internet Forum is offered for advice and assistance through conferencing Moderators. Few courses at open university have compulsory day schools and are of a daylong sessions that a student have got to be present in so as to pass the course online accessed (2014).

\section{Instructional Design System of Indira Gandhi National Open University (IGNOU) India}

Indira Gandhi National Open University established in 1985 by an act of Parliament, has constantly endeavored to construct a broad knowledge based society through comprehensive teaching instructions and methods. It increases the Gross Enrollment Ratio (GER) through 
high quality of teaching using the open and distance learning methods. It is serving the educational ambitions and objectives of more than 3 million students of India and other states with a network of 67 regional centers and 21 schools of studies. There are 29 overseas partner institutions and 2,667 learner support centers IGNOU online source, accessed (2014).

Indira Gandhi National Open University utilizes a range of latest technology and media in spreading the education. This reflects in the devised vision of the university having a focus on its objectives which states that Indira Gandhi National Open University is the National Resource Centre for Open and Distance Learning, with international recognition and presence shall provide seamless access to sustainable and learner-centric quality education, skill up-gradation and training to all by using innovative technologies and methodologies, ensuring convergence of existing systems for large-scale human resource development, promoting integrated national development and global understanding IGNOU online source, (2008).

\section{Instructional Design System of Allama Iqbal Open University}

The main objective of Allama Iqbal Open University establishment was to provide educational opportunities to people and to those who are not able to go away from jobs and homes. It has unlocked opportunities to get education the working class and access at the doorsteps for the females too Brief History of AIOU, online (2014). Allama Iqbal Open University has developed and possesses its own instructional design process. There are committees of courses at the departmental level to develop the courses and same nature of committees exists at faculty level, known as faculty board. The monetary decision of these committees is forward to the academic planning and development committee and the decisions concerning research and media is forwarded to research and technology committee. After due course the decision is sent to the academic and executive councils for final sanction and execution. The university is based upon distance education and uses multimedia approach. The most important parts of its instructional design are: self-learning printed text and supplementary material, broadcast on TV and Radio, seminar of instructions, course assignment, tutorial support and use of educational technology.

\section{Centre for Instructional Design of AIOU}

The Allama Iqbal Open University is a distance education body that provides variety of teaching from general to professional level of the people in the whole country. Instructional design of Allama Iqbal Open University is a methodical way to formulate course instructions for the students. In May 2011 the centre for instructional design was established with an objective to develop technology integrated instructions and evaluation approach, reconsider the course to mirror technology well-off environment and increasing media for web based instructional functions. To develop a high quality instructional material not contrary to standard and needs of local constraints is the main task of the centre. It also organizes training of media developers, tutors, academicians, course writers, scholars and researchers with reference to new developments of instructional design. Further, to formulate the policy guidelines and integration of print materials into technology based learning is the objective and function of the centre. The Allama Iqbal Open University instructional design system modifies along with modern technology based tools in order to facilitate distance learners in their environments Staff Report, on-line (2012).

\section{IMPLICATIONS OF THE INSTRUCTIONAL DESIGN}

Instructional design is the systematic specification of instructions. It proposes objectives, presentation of materials, activities, guidance, feedback and evaluation. It applies learning principles to decisions about contents, interactional methods, use of media and delivery system. The goal is to ensure instructional quality, effectiveness, efficiency and enjoyment. 
The purpose of instructional design is to maximize the value of the instructions for the learners. The main purposes of the instructional design include identifying instructional out-comes, developing instructional contents and established how instructional effectiveness will be evaluated. Allama Iqbal Open University has its own instructional design system having important components of print material, allied material, tutorial support, assignments, e-learning, broadcast media and innovative multimedia approach of centre for instructional design. This study will be significant and beneficiary for the course writers, students, tutors, course reviewers, course editors and media producers or stakeholders of the instructional design system. They will be able to comprehend, reform, design and launched the innovative instructional design system for distance learners. The benefits and implications of instructional design are: development of quality in education, promote co-ordination activities in the system, makes accurate and efficient delivery system, improve innovative methodologies and enhanced evaluation activities.

\section{METHODOLOGY}

Proper methodology has to be selected to satisfy the information of any research study, suitable tools for data collection and analysis are chosen Mouton (2001). Keeping in view the nature of this study a descriptive i.e. survey form of research was used. It deals with the Instruction Design System of Allama Iqbal Open University: a vehicle of improvement or mere a salogon in organized and arranged manners.

\section{Instrument}

Questionnaire was used as a tool for data collection. Questionnaires in general consist of number of statements for the measurement of subject variables regarding the analysis of the Instruction Design System of Allama Iqbal Open University: a vehicle of improvement or mere a salogon. For this study these questionnaires were used.

1. Questionnaire for Course Writers of the AIOU.

2. Questionnaire for Course Reviewers of AIOU.

3. Questionnaire for Media Producers of the AIOU.

All statements of the questionnaires were closed ended, provided descriptions of five levels namely strongly agree, agree, uncertain, disagree and strongly disagree, so that quantitative judgment might be made. Respondents checked one of these levels which he/she thought to be most appropriate.

\section{Validity and Reliability of the Instrument}

Pre-test is one of the states which are carried out after designing the instruments. It is carried out to determine its effectiveness and problems. After initial construction of the questionnaires, editing was made. Questionnaire of course writers was presented to five experts for professional validation, questionnaire for course reviewers was served to three experts and questionnaire for media producers was presented to one expert. Although validity of a research tool is important, yet it is worthy to determine its reliability. Reliability refers to the consistency of research tool in data collection with accuracy Wallen and Fraenkel (2001). Similarly Mooren (2002) argues that "when items are used to form a scale they need to have internal consistency. Cronbach's Alpha is a tool for assessing the reliability of scales. It is a useful coefficient for assessing internal consistency. So the Cronbach Alpha was calculated to determine the internal consistency of the tools through SPSS Statistics Version 16. These questionnaires were amended in the light of the observations and suggestions.

After professional validation, the "instructions" were placed as "cover page" on each questionnaire. The statements of each questionnaire were typed in such a manner that statement should become clear and legible. Sufficient space was left for "marking" the respondents. After professionally up-dating questionnaires were administered for pilot 
testing, the questionnaire for course writers was presented to three respondents, questionnaire for course reviewers was administered to two respondents, where as questionnaire for producers was presented to one producer. Their observations regarding content and language were accommodated before actual lunch.

Population

The population was comprised as Table 1.

Table 1

Population sample ratio

\begin{tabular}{clccccc}
\hline S.No & Population Category & Population & Sample & $\%$ & Return & $\%$ \\
\hline 1 & Course Writers at AIOU & 75 & 75 & 100 & 63 & 84 \\
2 & Course Reviewers at AIOU & 25 & 25 & 100 & 21 & 84 \\
3 & Media Producers at AIOU. & 10 & 10 & 100 & 10 & 100 \\
\hline
\end{tabular}

\section{Administration of Tool}

The researcher personally and through pre-paid postage administered the instruments to the sample population. The filled questionnaires were collected back personally and through postal mail from the sample population. 63 questionnaires $(84 \%)$ from course writers were received back, 21 questionnaire (84\%) from course reviewers and $10(100 \%)$ from media producers were received back.

Statistical Analysis of Data

Through SPSS Statistics Version 16 Percentage, Mean Score and Variance was determined.

(1) Percentage $=$ Obtained Responses $\times 100$

Total Responses

(2) Mean Score = 5FSA+4FA+3FUNC+2FDA+1FSA.

$\mathrm{N}$

(The Mean Score could range from 1 to 5 , the score 3 and above was taken as favorable).

(3) Variance $=$ ?

FINDINGS AND DISCUSSION

Table 2

Responses of course writers

\begin{tabular}{|c|c|c|c|}
\hline S.NO & Statement & Mean Score & Variance \\
\hline 01 & $\begin{array}{l}\text { Need assessment of the course is conducted before the } \\
\text { course development. }\end{array}$ & 3.5 & 1.35 \\
\hline 02 & Course team is selected, keeping their specialization. & 3.7 & 1.54 \\
\hline 03 & $\begin{array}{l}\text { Courses are developed with standardized techniques of } \\
\text { instructional design. }\end{array}$ & 3.6 & 1.70 \\
\hline 04 & Course contents are placed in logical order. & 4.1 & 0.51 \\
\hline 05 & Creativity is maintained in course development process. & 2.9 & 1.58 \\
\hline 06 & Courses are also provided on e-learning format. & 2.7 & 1.70 \\
\hline 07 & E-assessment techniques should be used in the courses. & 3.8 & 1.19 \\
\hline 08 & $\begin{array}{l}\text { Evaluation system is suitable to evaluate all components of } t \\
\text { instructional design. }\end{array}$ & 2.6 & 1.48 \\
\hline 09 & $\begin{array}{l}\text { Communication strategies should be up-dated for the } \\
\text { courses. }\end{array}$ & 3.6 & 1.62 \\
\hline
\end{tabular}


10 Instructional design of AIOU should be more innovative.

$4.2 \quad 0.6$ Modern educational technology should be used for $4.1 \quad 0.63$ instructional design.

12 Professional development opportunities are available for all stakeholders of the instructional design at AIOU.

$2.8 \quad 1.53$

Table 2 indicates that the opinion of $58.7 \%$ respondents was favour of need assessment, $65 \%$ of respondents were of the view that course team is selected, keeping their specialization $($ Var $=1.54)$. Course writers $(60.4 \%)$ agreed that courses are developed with standardized techniques of instructional design and course contents are placed in logical order $(\mathbf{8 2 . 5 \%})$. Course Writers (Mean $=2.9$ ) did not favour that creativity is maintained in course development process and courses are also provided on e-learning format. Course writers $65.1 \%$ agreed that e-assessment techniques should be used in the courses. Variance 1.71 presented that communication strategies should be up-dated for the courses. Majority (85.7\% respondents agreed that instructional design of AIOU should be more innovative (Var $=0.69) .79 .3 \%$ respondents agreed that modern educational technology should be used for instructional design. Majority $(47.6 \%)$ disagreed that professional development opportunities are available for all stakeholders of the instructional design at AIOU. (Var = 1.53)

Table 3

Responses of course reviewers

\begin{tabular}{|c|c|c|c|}
\hline S.NO & Statement & Mean Score & Variance \\
\hline 01 & Need assessment is carried-out for reviewing the courses. & 3.7 & 0.92 \\
\hline 02 & Course objectives are clearly measureable. & 3.8 & 0.57 \\
\hline 03 & $\begin{array}{l}\text { All activities of the course design should be objective } \\
\text { oriented. }\end{array}$ & 4.0 & 0.91 \\
\hline 04 & $\begin{array}{l}\text { Course reviewers are selected, keeping their } \\
\text { specialization. }\end{array}$ & 2.9 & 1.15 \\
\hline 05 & $\begin{array}{l}\text { Courses are developed with standardized techniques of } \\
\text { instructional design. }\end{array}$ & 3.8 & 1.27 \\
\hline 06 & Contents of the courses are appropriate for learners need. & 3.4 & 1.56 \\
\hline 07 & Course contents are placed in logical order. & 3.9 & 0.95 \\
\hline 08 & Media support is provided in the courses. & 3.1 & 1.22 \\
\hline 09 & Courses are also provided on e-learning format. & 2.0 & 1.96 \\
\hline 10 & E-assessment techniques should be used in the courses. & 3.5 & 1.46 \\
\hline 11 & Evaluation process is transparent at AIOU. & 3.1 & 1.53 \\
\hline 12 & $\begin{array}{l}\text { Communication skills of the learners should be developed } \\
\text { by instructional design of AIOU. }\end{array}$ & 4.3 & 2.35 \\
\hline 13 & Instructional design of AIOU should be more innovative. & 4.1 & 0.82 \\
\hline 14 & $\begin{array}{l}\text { The instructional design process of AIOU is based on } \\
\text { distance education. }\end{array}$ & 2.9 & 1.64 \\
\hline 15 & $\begin{array}{l}\text { Resources are to be used to design advance instructional } \\
\text { design model at AIOU. }\end{array}$ & 3.8 & 1.67 \\
\hline 16 & $\begin{array}{l}\text { Modern educational technology should be used for } \\
\text { instructional design. }\end{array}$ & 4.1 & 0.93 \\
\hline
\end{tabular}

Table 3 shows that majority (71.4\%) respondents agreed that need assessment is carriedout for reviewing the courses and course objectives are clearly measureable $($ Var $=0.57)$. All the (76.2\%) Reviewers agreed that all activities of the course design should be objective 
oriented $($ Mean $=4.0)$. Majority $(47.7 \%)$ respondents remained uncertain that course reviewers are selected, keeping their specialization. Majority $(71.5 \%)$ agreed that courses are developed with standardized techniques of instructional design. Majority $(52.4 \%)$ were of the view that contents of the courses are appropriate for learners need. $71.5 \%$ respondents agreed that course contents are placed in logical order (Var $=0.95)$. Majority $(42.8 \%)$ agreed that media support is provided in the courses. Reviewers $(61.9 \%)$ disagreed that courses are also provided on e-learning format (Mean $=2.0$ ). Majority $(57.1 \%)$ respondents agreed that e-assessment techniques should be used in the courses. Majority $(61.9 \%)$ respondents agreed that communication skills of the learners should be developed. All the $81 \%$ respondents agreed that instructional design of AIOU should be more innovative. Majority $(66.7 \%)$ agreed that resources are to be used to design advance instructional design model. $\mathbf{8 1 \%}$ respondents were agreed that modern educational technology should be used for instructional design (Mean $=4.1$ ).

Table 4

Responses of media producers

\begin{tabular}{|c|c|c|c|}
\hline S.NO & Statement & Mean Score & Variance \\
\hline 01 & $\begin{array}{l}\text { Need assessment is carried-out for the production } \\
\text { process. }\end{array}$ & 4.1 & 0.33 \\
\hline 02 & $\begin{array}{l}\text { Course objectives of the AIOU courses reflect educational } \\
\text { needs of the learners. }\end{array}$ & 4.0 & 0.89 \\
\hline 03 & $\begin{array}{l}\text { Producers have a systematic approach in their production } \\
\text { activities. }\end{array}$ & 3.6 & 1.6 \\
\hline 04 & $\begin{array}{l}\text { Learners based activities are provided in the course } \\
\text { production. }\end{array}$ & 3.6 & 2.05 \\
\hline 05 & Creativity is maintained in course production process. & 3.9 & 1.44 \\
\hline 06 & The recording voice matched with script requirements. & 4.1 & 0.99 \\
\hline 07 & Words and illustration are blended in integrated manners. & 4.0 & 0.67 \\
\hline 08 & Appropriate media is selected for transmission of courses. & 4.2 & 0.18 \\
\hline 09 & $\begin{array}{l}\text { Modern educational technology is helpful in developing } \\
\text { instructional design. }\end{array}$ & 4.3 & 1.57 \\
\hline 10 & Courses are developed according to learner's level. & 3.8 & 1.74 \\
\hline 11 & $\begin{array}{l}\text { Communication skills are developed in the learners } \\
\text { through AIOU courses. }\end{array}$ & 3.8 & 2.18 \\
\hline 12 & $\begin{array}{l}\text { Producers ensure that written scripts are according with } \\
\text { the specific objectives. }\end{array}$ & 3.9 & 0.55 \\
\hline 13 & Audio-visual material is supporting the course material. & 3.8 & 1.52 \\
\hline 14 & $\begin{array}{l}\text { Modern evolution techniques should be used in course } \\
\text { production process. }\end{array}$ & 3.5 & 0.95 \\
\hline 15 & $\begin{array}{l}\text { The instructional design process of AIOU is based on } \\
\text { distance education. }\end{array}$ & 4.0 & 0.67 \\
\hline 16 & $\begin{array}{l}\text { Evaluation system of AIOU is suitable to evaluate } \\
\text { instructional design system. }\end{array}$ & 3.1 & 0.99 \\
\hline
\end{tabular}

Table 4 presents that majority (90\%) respondents were agreed that need assessment is carried-out and $\mathbf{8 0} \%$ agreed that course objectives reflect educational needs of the learners. $70 \%$ were agreed that producers have a systematic approach in their production activities. Majority $\mathbf{8 0} \%$ agreed that creativity is maintained in course production process. Media producers $\mathbf{8 0} \%$ were in favour that the recording voice matched with script requirements (Mean = 4.1). 90\% respondents were agreed that words and illustration are blended in integrated manners. All $\mathbf{1 0 0 \%}$ agreed that appropriate media is selected for transmission of 
courses. Media Producer $90 \%$ were agreed that modern educational technology is helpful in developing instructional design(Mean $=4.3$ ). $60 \%$ were agreed that communication skills are developed in the learners through AIOU courses. Majority $90 \%$ were agreed that Producers ensure that written scripts are according with the specific objectives. It was $\mathbf{7 0 \%}$ opinion in the favour that audio-visual material is supporting the course material. Majority $60 \%$ agreed that modern evolution techniques should be used in course production process. It was a general view that evaluation system of AIOU is suitable to evaluate instructional design system.

\section{CONCLUSIONS OF THE STUDY}

1. Need assessment of the course is conducted before the course development. Courses are developed with standardized techniques of instructional design and contents are placed in logical order.

2. Creativity is maintained in course development process and courses are also provided on e-learning format. E-assessment techniques should be used in the courses.

3. Communication strategies should be up-dated for the courses and instructional design of AIOU should be more innovative.

4. Modern educational technology should be used for instructional design and professional development opportunities are available for all stakeholders of the instructional design at AIOU.

5. Media support is provided in the courses. The instructional design process of AIOU is based on distance education and resources are to be used to design advance instructional design model at AIOU.

6. Learners based activities are provided in the course production. Communication skills are developed in the learners through AIOU courses.

\section{RECOMMENDATIONS}

1. Media laboratory may be established at AIOU for development and launching of innovative multimedia based education programs.

2. Centre for Instructional Design may be developed for enhancement of delivery system at AIOU.

3. Creativity may be maintained in course production process at AIOU.

4. There is need to select appropriate media for transmission of courses.

5. It was concluded in the study that instructional design of AIOU may be modified to meet the future needs.

6. E-learning and e-assessment techniques may be developed at AIOU.

7. Systematic and continuous research may be undertaken for future vision of the instructional design system by AIOU.

BIODATA and CONTACT ADDRESSES of the AUTHORS

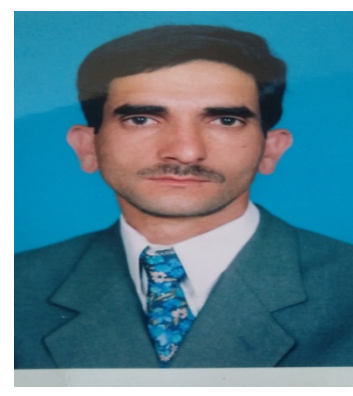

Muhammad ASHFAQ Ph.D Scholar, is Senior Secondary School Teacher in Government High School Kokal Barseen Abbottabad Department of Elementary \& Secondary Education Khaber PakhtoonKhwa PAKISTAN. His main areas of interest and research is teaching methodologies, guidance \& counseling, educational psychology, socialization, cocurricular activities, students support services and quality of education. He teaches English, Pakistan Studies, Geography, Literal and Sports Development Activities at Secondary Education. 
Muhammad ASHFAQ

Senior Secondary School Teacher

Department of Elementary \& Secondary Education

Khaber PakhtoonKhwa Pakistan

Mobile: +92-347-5057356

Email: mashfaq7869@gmail.com

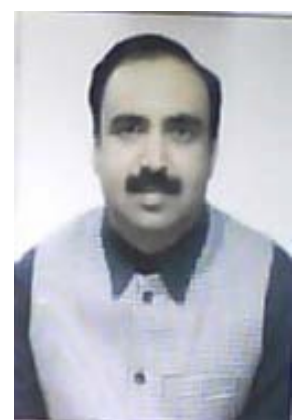

Muhammad Ajmal CHAUDRY Ph.D is Assistant Professor in the department of distance, non-formal \& continuing education, Allama Iqbal Open University Islamabad PAKISTAN. His research activities consisted of a wide range area such as Teacher Training, Science Education, and Total Quality Management (TQM) in Education and curriculum Development, Attitudinal Psychology, Comparative Education and Assessment. He teaches different courses at M.A Education, M.Ed and B.Ed programs. He is also research consultant, supervisor and co-coordinator of multi aspects research studies and projects at Higher Education Commission of Pakistan and world education organizations.

Muhammad Ajmal CHAUDRY

Assistant Professor

Department of distance non-formal \& continuing education,

Allama Iqbal Open University Islamabad PAKISTAN

Telephone: +92-51-9057246 Fax: +92-51-9250056

Mobile: +92-305-5592322

+92-315-7000484

Email: drajmal@aiou.edu.pk

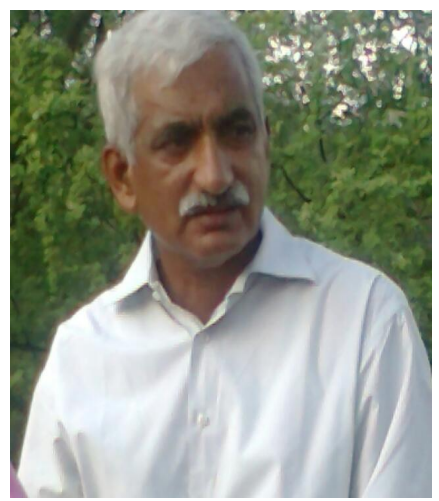

Muhammad Javed IQBAL Ph. D is Director of Mass Education, Sarhad University of Science and Technology Peshawar PAKISTAN. He was Dean Faculty of Education AIOU PK. His areas of interest and research services are in curriculum development, instructional design and strategies, educational psychology, educational philosophy, quality assurance, innovative teaching and learning methods, educational technology and mass education. He serves in different GOs \& NGOs national and international organizations as research supervisor, consultant and advisor.

Muhammad Javed IQBAL (Professor)

Director, Mass Education,

Sarhad University of Science and Technology Peshawar Pakistan.

Telephone : +92-51-2212962

Mobile : +92-331-5326759

Email: javediqbal1941@yahoo.com 


\section{REFERENCES}

Annick M. Brennen, (2001), Philosophy of Education, Andrews University Extension Center, School of Education, Northern Caribbean University.

Brief History of AIOU, Available at: [Online] http://www.aiou.edu.pk/BriefHistory.asp Accessed on 17/01/2014

Definitions of Instructional Design, Adapted from "Training and Instructional Design", Penn State University, [Online] Available at: http://www.umich.edu/ ed626/define.html

Dick, Carey, L. (1990), The Systematic Design of Instruction 3rd edition Harper Collins

Edmonds G.S., Robert C., Branch and Prachee M., (1994), A Conceptual Framework for Comparing Instructional Design Models, ETR\&D, Springer, VoL 42, No. 4.

Morrison, J., L. \& Aldrich, C. (2003), Simulations and the learning revolution: An interview with Clark Aldrich. The Technology Source. [Online] Available at:

http://64.124.14.173/default.asp?show=article\&id $=2032$

Morphew (2000), Learning and Instructional Systems Design, [Online] Available at: http:// uir.unisa.ac.za/bitstream/handle/10500/4245/04Chap\%203_Learning\%20and\%20in

Moore, M.M \& Tait A. (2002), Open and distance learning: Trends, policy and strategy consideration, UNESCO.

Parveen B., Towards Innovative Library Services: A Case Study of Indira Gandhi, National Open University, India, 2014, IGI Global, Chapter 12 p. 2

Preamble, IGNOU, [Online] Available at: http://www.ignou.ac.in/ignou/aboutignou/ profile/2

Prema P. N., (2011), New Media Concepts, Technical writing \& Instructional Designing, [Online] Available at: http://whizcom.blogspot.com/2011/03/technical-writing-html

Shambaugh N \& Magliaro.G.S., (2006), Instructional design. New York: Pearson education.

Simonson, M., Smaldino, S., Albright, M., \& Zvacek, S. (2006), Teaching and learning at a distance (3rd ed.). Upper Saddle River, NJ: Pearson Education, Inc.

Smith \& Ragan, (1993), The Smith/Regan Model, The Morrison/Ross/Kemp Model, and the OAR Model, Instruction Design Models (EDUC 534)

Smith, P. L. \& Ragan, T. J. (2004), Instructional design (3rd Ed.). Danvers, MA: John Wiley \& Sons.

Staff Report of May, 09. 2012, AIOU allocates Rs $80 \mathrm{~m}$ to upgrade Centre for Instructional Design, [Online] Available at: http://archives.dailytimes.com.pk/islamabad/09-May 2012/aiouallocates-rs-80m-to-upgrade-centre-for-instructional-design

Wallen, N. E. \& Fraenkel, J. R. (2001). Educational research: A guide to the process (2nd ed.). Mahwah, NJ: Lawrence Erlbaum Associates, Publishers. 